\title{
The Impact of Collaborative Writing on EFL Learners' Writing Development: A Longitudinal Classroom-Based Study in Saudi Arabia
}

\author{
Khaled Salem Aldossary \\ Department of English Language and Translation \\ College of Languages and Translation \\ King Saud University, Riyadh, Saudi Arabia \\ Email: kdossary@ksu.edu.sa
}

Received: 4/23/2021

Accepted: 8/26/2021

Published:

\begin{abstract}
No previous studies have employed sociocultural theory and the notion of collaborative dialogue to examine collaborative writing in Saudi Arabia, where students favor writing individually. Exploring this topic is significant because of the importance the Saudi education system places on learning English, especially at the university level. Therefore, this longitudinal classroombased study tested how collaborative writing affected the development of university students learning English as a foreign language in Saudi Arabia. The 46 participants were evenly divided into a control group, who wrote essays individually, and an experimental group, who worked on essays in small groups. Both groups took a pre-test before the eight-week intervention and a post-test at the end. The experimental group also took an end-of-study questionnaire. Although both groups showed improvement, the experimental group improved significantly more on the post-test than the control group and expressed positive attitudes toward collaborative writing on the questionnaire. The study concludes with theoretical and pedagogical implications and recommendations for future research.

Keywords: Collaborative writing, group work, individual writing, learner perceptions, sociocultural

Cite as: Aldossary, K. S. (2021). The Impact of Collaborative Writing on EFL Learners' Writing Development: A Longitudinal Classroom-Based Study in Saudi Arabia. Arab World English Journal, 12 (3) 174 -185. DOI: https://dx.doi.org/10.24093/awej/vol12no3.12
\end{abstract}




\section{Introduction}

Writing is a recursive process in which students plan, formulate ideas, and revise their work to generate a final written product (Storch, 2013). In such an activity, learners engage in cognitive tasks to solve problems and make their thoughts concrete and meaningful. According to many studies on second language (L2) writing, working in pairs and small groups in the classroom can give learners more opportunities to work together to solve language problems, helping them become better writers (e.g., Chen \& Hapgood, 2019; Dobao, 2012; McDonough et al., 2016; Storch, 2013; Zenouzagh, 2020; Zhang, 2018). According to Donato (1994), peer interaction provides ample opportunities for learners to pool their language resources and coconstruct knowledge, a process called "collective scaffolding."

A highly useful practice that promotes collective work in L2 writing classrooms is collaborative writing. Collaborative writing is a way of assigning more than one student (in pairs or small groups) to complete a given task. In such a task, the students (i.e., co-authors) interact, negotiate ideas and meaning, and together produce a single text (Storch, 2013). Research on this practice in L2 classrooms has received increasing attention in the last two decades. Storch (2018) grouped this research into three main categories: (a) the use of languaging in collaborative writing, (b) the benefits of languaging in terms of language gains and text production, and (c) collaborative writing mediated by technology. The term "languaging" refers to learners using language to deliberate about language or make sense of complex information (Swain, 2006). One form of languaging is collaborative dialogue (Swain, 2006, 2010), which occurs when pairs or groups of students use mediating language to solve problems (Swain \& Lapkin, 2002).

Relatively few empirical longitudinal studies have examined how collaborative writing affects L2 learners, and there is a need for more classroom-based studies in this area (Storch, 2018) that implement a pre-/post-test design (Sato \& Ballinger, 2016). As pointed out in Zhang and Plonsky (2020), most studies on collaborative writing have focused on pairs of students, paying little attention to small groups. In addition, such research in Saudi Arabia is scarce and has usually only targeted learner perceptions (e.g., Alkhalaf, 2020), tended to be of relatively short duration, or failed to use a theoretical framework (e.g., Alammar, 2019). Informed by Vygotsky's (1978) sociocultural theory, the present study sought to address this gap with Saudi learners of English as a foreign language (EFL) by answering the following research questions:

1. Is there a significant difference between the writing of individuals and the collaborative writing of small groups?

2. What do students think of collaborative writing?

\section{Literature Review}

\section{Theoretical Background}

Although writing has long been considered a solitary act performed in classrooms, theories of L2 learning (e.g., the interaction hypothesis, sociocultural theory) encourage collaborative learning and writing (Storch, 2013). These theories highlight the importance of shared responsibilities, negotiation, and mutual leadership. Numerous studies have demonstrated how collaborative writing improves L2 learning through interaction. Pair work or small groups in L2 writing classrooms provide learners with opportunities to engage in meaningful communication and develop their communicative competence, in accordance with communicative approaches to language learning. For example, learners working in pairs or small groups are more likely to 
discuss ideas, ask for clarifications, and make suggestions. With the scaffolding provided during interactions in collaborative writing, learners notice their weaknesses and exchange knowledge, processes that can lead to L2 development. It is thus unsurprising that collaborative writing finds support from psycholinguistic and sociocultural theories of L2 acquisition. From a psycholinguistic perspective, collaborative writing activities create opportunities for learners to interact and communicate while writing. In this process, learners negotiate meaning, exchange feedback, and produce a modified output that can contribute to their L2 development (Long, 1996). These deliberations about language allow students to notice particular language forms and provide a source of comprehensible input for L2 learning (e.g., Gass et al., 2011; Namaziandost \& Nasri, 2019).

From a sociocultural standpoint, drawing on Vygotsky's (1978) work, cognitive development takes place in a sociocultural context and grows out of social and cultural interactions. Vygotsky suggested that interactions between a novice and an expert, or peers with slightly more experience, could contribute to the novice's cognitive development. Such assistance is commonly known as "scaffolding" in the literature (Wood et al., 1976). Studies have shown that scaffolding can occur among peers working in pairs or groups (e.g., Aldossary, 2017; Donato, 1994). Research informed by sociocultural theory regards classroom interactions as opportunities for learners to deliberate about language through co-constructing new knowledge or consolidating existing knowledge. Such use of language can "play a key role in all cognitive development" (Storch, 2013, p. 13). Based on these theoretical principles, learners should be encouraged to collaborate to improve their L2 writing (Storch \& Aldosari, 2010).

\section{Collaborative Second Language Writing}

Over the past two decades, studies have examined the effectiveness of collaborative writing in L2 writing classrooms (e.g., Al Tai, 2015; Aminloo, 2013; Dobao, 2012; McDonough et al., 2019; Shehadeh, 2011; Zenouzagh, 2020) and learner attitudes about collaborative writing (e.g., Alkhalaf, 2020; Dobao, 2020; Dobao \& Blum, 2013). Such studies have generally reported collaborative writing had a positive effect on L2 learning.

Previous studies comparing individual and collaborative activities have supported collaborative writing in L2 writing classrooms. Using sociocultural theory, Dobao (2012) compared the language-related episodes (LREs) produced by second-year students at a large US university while doing collaborative writing in pairs or small groups of four. Learners who worked in groups produced more LREs than those who worked in pairs, and the groups solved a higher proportion of LREs correctly. In a similar study in a secondary school, Al Tai (2015) examined the impact of writing individually, writing in pairs, and writing in groups (of three or four) among 45 female Omani students. Learners who worked in groups received better grades and produced longer, more accurate texts. The study concluded that "group work leads to a higher achievement in terms of task response and fluency" (p. 166).

Some studies using a pre-/post-test design have found collaborative writing to have immediate (e.g., Aminloo, 2013; Shehadeh, 2011) and long-term benefits (e.g., Zenouzagh, 2020). For example, Shehadeh's (2011) longitudinal study investigated the impact of collaborative writing on L2 writing. Learners in the experimental group $(n=18)$ wrote in pairs, while those in the control group $(n=20)$ wrote about the same topics but individually. Learners 
who worked in pairs showed more improvement in content and organization than those who worked individually. Thus, collaborative writing provided learners with opportunities for planning, discussion, and pooling linguistic resources. In this way, engaging in such cognitive processes in collaborative writing tasks "might have been a source of L2 learning" (p. 297).

Other studies have reported positive benefits of collaborative writing on global and local aspects of writing. For example, using a pre-/post-test design, Khatib and Meihami (2015) found that learners who engaged in collaborative writing showed a significant improvement in content, organization, and grammar compared to those who wrote individually. Zenouzagh (2020) likewise showed that EFL learners who engaged in collaborative writing improved their syntactic complexity and sustained that improvement in the delayed post-test compared to those who wrote individually. McDonough et al. (2019) examined 128 EFL students at a university in Thailand under three conditions: collaborative writing, collaborative prewriting, or no collaboration. Students who worked in groups produced more accurate paragraphs than those in the prewriting and no-collaboration conditions.

Several studies exploring L2 students' perceptions of collaborative writing in pairs or small groups have reported positive results (e.g., Alkhalaf, 2020; Dobao, 2020; Dobao \& Blum, 2013). For example, Alkhalaf (2020) explored the attitudes of 50 Saudi EFL female learners toward collaborative writing and the challenges they encountered. The participants engaged in several small-group collaborative writing activities over 15 weeks. Overall, learners had positive attitudes toward collaborative writing, and the majority of them were satisfied with the quality of their final written product. However, they also reported several challenges, such as peers having low L2 proficiency and not contributing equally.

Dobao and Blum (2013) explored 55 Spanish students' perceptions of writing in pairs and small groups. Nearly all participants considered collaborative writing beneficial. Those who worked in pairs reported that the experience offered ample opportunities to take an active part in the activity. Those who worked in groups felt there were more ideas and knowledge to share in a group, which could contribute to language improvement. A recent study conducted by Dobao (2020) at a university in the US investigated how heritage language (HL) learners $(n=8)$ and L2 learners $(n=10)$ perceived their mixed HL-L2 interactions in two Spanish classes. To that end, the participants took a questionnaire at the beginning of the quarter, completed a series of collaborative writing tasks in pairs over the course of 10 weeks, and then took an end-of-quarter questionnaire. Both groups had a very positive perception of collaborative writing activities and felt their mixed interactions led to language gains.

Research on collaborative writing in L2 contexts has generally shown positive results, particularly with stimulating cognitive processes and providing opportunities for socially constructed learning through scaffolding. However, few studies have employed sociocultural theory to investigate collaborative writing among EFL learners in Saudi Arabia, an underresearched language-learning context where teacher-centered instruction is predominant. The current longitudinal study thus contributes to advancing the understanding of collaborative writing in the Saudi EFL context. 


\section{Method}

\section{Participants}

Participants were randomly selected and consisted of 46 male Saudi EFL undergraduate students enrolled in a Writing II course in the Department of English Language and Translation in the College of Languages and Translation at King Saud University. Their ages ranged from 19 to 21. The participants were randomly divided into two groups: control $(n=23)$ and experiment $(n=23)$. The study took place in the first semester of the 2019-2020 academic year. All participants were native Arabic speakers who had passed the prerequisite Writing I course before enrolling in Writing II (taught for 150 minutes per week).

\section{Instruments}

The researcher employed two instruments for data collection: a pre-/post-writing test and a post-experiment questionnaire.

\section{Writing Test}

As part of their regular classroom activities, all participants wrote a paragraph of 120-150 words (timed for 30 minutes) about their neighborhood before and after the treatment. The tests were similar in terms of topic, paragraph length, and genre to ensure reliability. Participants were rated using a modified version of the ESL Composition Profile developed by Jacobs et al. (1981). The rubric covered all major aspects of writing, including content, organization, vocabulary, language use, and mechanics. Each writing component was marked on a 4-point scale (where 4 = "excellent," and 1 = "very poor"), providing each paragraph with a score out of 20 points. Two associate professors of applied linguistics from the Department of English Language and Translation at King Saudi University evaluated each writing sample individually (i.e., each writing sample was rated twice). A Pearson correlation coefficient helped determine whether there was an acceptable level of inter-rater reliability. Table 1 shows the correlation between the two raters' scores for pre- and post-tests across the two groups.

\section{Table 1. Correlation of rater scores for pre-and post-tests across groups}

\begin{tabular}{lcccc}
\hline & \multicolumn{2}{c}{ Control Group } & \multicolumn{2}{c}{ Experimental Group } \\
\hline Test & Pre-Test & Post-Test & Pre-Test & Post-Test \\
\cline { 2 - 5 } Pearson Correlation & .662 & .753 & .684 & .712 \\
Sig. (2-tailed) & .001 & .011 & .001 & .001 \\
$N$ & 23 & 23 & 23 & 23 \\
\hline
\end{tabular}

The analysis showed a significant positive correlation between the two raters across group tests $(\alpha \leq 0.01)$. This finding suggested the inter-rater reliability for both groups' pre-tests and post-tests was sufficiently high.

\section{Questionnaire}

The 13-item questionnaire was based on previous studies to elicit participants' perceptions of collaborative writing's effect on their writing skills. Item 13 had negative wording to ensure participants read the items carefully. Participants rated items on a 5-point Likert scale $(5=$ "strongly agree," 4 = "agree," 3 = "undecided," 2 = "disagree," and 1 = "strongly disagree"). The means were classified as "strongly disagree" between 1 and 1.80, "disagree" between 1.81 and 2.60, "no opinion" between 2.61 and 3.40, "agree" between 3.41 and 4.20, and "strongly agree" 
between 4.21 and 5. Eight English university professors checked the questionnaire for clarity and appropriateness to ensure its validity. The researcher amended the questionnaire based on their suggestions and piloted it with 10 students taking Writing II with a different instructor. A Cronbach's alpha of 0.80 indicated the questionnaire was reliable.

\section{Procedures}

The study randomly divided participants into two groups: experimental and control. In the experimental group, participants worked in small groups of three to four, writing about eight topics in eight weeks. The control group did the same work individually instead of in groups and only received feedback at the end of the study. This procedure avoided the possible impact of other variables (e.g., peer feedback, teacher corrective feedback).

Both groups of participants took a pre-test before the intervention. The experimental group then received a 60-minute training session to acquaint them with collaborative writing and engaged in pre-task modeling of collaboration. The researcher taught both groups throughout the semester, during which they engaged in weekly writing tasks for eight weeks. Participants in the experimental group changed partners for every session. At the end of the intervention, both groups took a post-test. The researcher monitored and guided all writing tasks in both groups, collecting their written drafts at the end of every class. During the sessions, the researcher reminded participants in the experimental group to work together on the whole writing process, i.e., prewriting, drafting, revising, editing, and producing a final written product. The researcher also took observation notes during the sessions.

The experimental group took an online questionnaire (via the Qualtrics software program) at the end of the study to elicit their perceptions of collaborative writing. The researcher explained the questionnaire, elaborated on the items, answered any questions, and asked participants to complete the questionnaire according to their perceptions.

The researcher carried out an independent-samples $t$-test to assess participants' writing ability on the pre-test and to measure their gains between the pre- and post-tests. The questionnaire data were processed and statistically analyzed using SPSS (Version 21).

\section{Results}

\section{Collaborative Writing and Writing Gains}

The first research question assessed the influence of collaborative writing on Saudi EFL students' writing ability. The researcher performed an independent-samples $t$-test to look for statistically significant differences between the control and experimental groups' pre-test scores (see Table 2).

Table 2. Pre-test results for control and experimental groups

\begin{tabular}{llllll}
\hline Group & $N$ & Mean & $S D$ & $t$ & Sig. \\
\hline Control & 23 & 12.2174 & 1.28 & \multirow{2}{*}{-1.263} & \multirow{2}{*}{.213} \\
\hline Experimental & 23 & 12.7174 & 1.39 & & \\
\hline
\end{tabular}

The analysis showed no statistically significant differences (at $\alpha \leq 0.01$ ) between the control and experimental groups' pre-test scores. This finding suggested the groups had similar writing ability at the time of the pre-test. The researcher performed another independent-samples $t$-test to 
Arab World English Journal (AWEJ) Volume 12. Number 3. September 2021

The Impact of Collaborative Writing on EFL Learners' Writing Development

Aldossary

look for a significant difference between the two groups' writing performance in the post-test (see Table 3).

Table 3. Post-test results for control and experimental groups

\begin{tabular}{lllllll}
\hline Group & $N$ & Mean & $S D$ & $t$ & Sig. & \multirow{2}{*}{ Eta $^{2}$} \\
\hline Control & 23 & 14.3043 & 1.04162 & \multirow{2}{*}{-4.020} & \multirow{2}{*}{.000} & \multirow{2}{*}{0.269} \\
\hline Experimental & 23 & 15.8913 & 1.58083 & & & \\
\hline
\end{tabular}

On the post-test, the experimental group $(M=15.89, S D=1.58)$ did significantly better (at $p$ $<0.05)$ than the control group $(M=14.30, S D=1.04)$. The difference in means $(M=1.59$, eta squared $=0.26$ ) suggested collaborative writing had a positive effect on students' writing.

\section{Learners' Perceptions of Collaborative Writing}

The second research question sought to determine learners' perceptions of the effectiveness of collaborative writing. Table 4 presents the means and standard deviations for responses to each item of the questionnaire.

As shown in Table 4, the means ranged from 4.13 to 4.83 , with standard deviations ranging from 0.39 to 0.82 . Items $1-12$ had mean scores ranging from 4.43 to 4.83 . These items fell within the "strongly agree" category, constituting 93\% of all questionnaire items. Item 13 had a mean score of 4.13 , which fell within the "agree" category and accounted for $7 \%$ of all items. Based on these results, participants held generally positive attitudes about group work and very positive attitudes about collaborative writing. For example, they strongly agreed that collaboration provided opportunities to share ideas and knowledge, which they believed helped improve their writing.

Table 4. Means and standard deviations of the questionnaire items

\begin{tabular}{lllcc}
\hline Item & Rank & Statement & Mean & $S D$ \\
\hline 1 & 1 & $\begin{array}{l}\text { Collaborative writing activities are very interesting and } \\
\text { enjoyable. }\end{array}$ & 4.83 & 0.39 \\
\hline 2 & 5 & $\begin{array}{l}\text { When I work in collaborative writing with my classmates, we } \\
\text { write grammatically correct texts. }\end{array}$ & 4.78 & 0.42 \\
\hline 3 & 2 & $\begin{array}{l}\text { Collaborative writing is an effective strategy that helps me } \\
\text { improve my writing skill. }\end{array}$ & 4.74 & 0.45 \\
\hline 4 & 6 & $\begin{array}{l}\text { Collaborative writing helps me acquire and use new vocabulary } \\
\text { correctly. }\end{array}$ & 4.74 & 0.45 \\
\hline 5 & 9 & $\begin{array}{l}\text { Collaborative writing helps me receive useful feedback from } \\
\text { classmates. }\end{array}$ & 4.70 & 0.47 \\
\hline 6 & 13 & $\begin{array}{l}\text { I want to be involved in more collaborative writing. } \\
\text { I prefer editing and revising texts in a group rather than }\end{array}$ & 4.65 & 0.49 \\
\hline 7 & 3 & $\begin{array}{l}\text { Writing collaboratively helps me share ideas and knowledge } \\
\text { with my classmates. }\end{array}$ & 4.57 & 0.59 \\
\hline 8 & 4 & $\begin{array}{l}\text { When I work in collaborative writing with my classmates, we } \\
\text { produce longer texts with more ideas. }\end{array}$ & 4.57 & 0.51 \\
\hline 9 & 7 & $\begin{array}{l}\text { Collaborative writing increases my understanding of my } \\
\text { responsibility. }\end{array}$ & 4.57 & 0.66 \\
\hline 10 & 8 & www.awej.org & 180 \\
\hline Arab World English Journal
\end{tabular}

ISSN: 2229-9327 
Arab World English Journal (AWEJ) Volume 12. Number 3. September 2021

The Impact of Collaborative Writing on EFL Learners' Writing Development

Aldossary

\begin{tabular}{llllc}
\hline 11 & 12 & $\begin{array}{l}\text { Collaborative writing in a group helps me get better scores in my } \\
\text { writing exams. }\end{array}$ & 4.47 & 0.77 \\
\hline 12 & 11 & $\begin{array}{l}\text { All students in my group perform an equal amount of work } \\
\text { during the activity. }\end{array}$ & 4.43 & 0.66 \\
\hline 13 & 10 & Some of my classmates do not accept my opinions. & 4.13 & 0.82 \\
\hline Overall Mean & & 4.61 & \\
\hline
\end{tabular}

After working in collaborative writing activities, participants felt they could write longer texts with fewer grammar errors and more ideas. In addition, the responses indicated that collaborative writing helped participants acquire new words and use them correctly in writing. Participants also believed that collaborative writing improved their performance in L2 writing exams. This finding could explain why they showed a strong preference for revising their texts in groups rather than individually. In addition, they could have been willing to engage in more collaborative writing because it fostered a sense of shared accountability. Participants strongly agreed that all group members contributed equally to the task but also reported that some members did not accept contrary opinions.

\section{Discussion}

This longitudinal study compared the impact of individual and small-group collaborative writing on Saudi EFL university learners' writing achievement and how they perceived collaborative writing. On the post-test, those who engaged in collaborative writing significantly outperformed those who wrote individually. This finding is consistent with previous research (e.g., Aminloo, 2013; Zenouzagh, 2020). The learning gains in this study could be due to several factors, such as pre-task training and learners' active interaction during collaborative writing sessions. The training before collaborative writing might have prepared learners to participate and raised their awareness of the merits of collaborative work. Previous research has highlighted the significance of providing well-structured training to motivate students for better participation and learning (Chen \& Hapgood, 2019) and increase contribution (Judd et al., 2010). Training could thus have stimulated learners to engage more vigorously in collaborative writing, resulting in more idea negotiation.

The observation notes showed that, during the collaborative writing sessions, learners engaged in lengthy deliberations in the target language, shared ideas, tried to keep each other focused, provided mutual assistance, and enjoyed the collaborative work. Such interaction in the target language can improve language learning (McDonough \& Sato, 2019; Storch, 2013). From a sociocognitive perspective, previous research has suggested that using the L2 for collaborative writing enhances cognitive development (e.g., Shehadeh, 2011). In collaborative writing, deliberations about language, as socially situated processes, can help co-construct new knowledge and consolidate existing knowledge. Therefore, interactions during collaborative writing likely played a major role in improving participants' writing by providing opportunities for languaging through collaborative dialogue. Such interactions could have also facilitated cognitive development.

Drawing on Swain's (2006) notion of collaborative dialogue and Donato's (1994) collective scaffolding, collaborative dialogue during collaborative writing activities could have allowed participants to think about language, direct each other's attention to linguistic problems, and 
elicit responses through suggestions, counter suggestions, and feedback. These deliberations could have helped students collectively scaffold their learning by consolidating existing knowledge and co-constructing new knowledge. Studies have shown that learners in small writing groups generally produced more extended L2 turns (e.g., Storch \& Aldosari, 2010) and benefited from a larger pool of knowledge (Dobao, 2014). Moreover, individuals in small groups generally relied on peer knowledge to solve problems instead of their own linguistic resources; in this sense, they pooled their linguistic resources to collectively scaffold their performance (Storch, 2013). Donato (1994) argued that collective scaffolding could enable learners in small groups to perform beyond their current linguistic knowledge, facilitating their L2 learning. Wigglesworth and Storch (2012) found similar evidence that discussions during collaborative tasks could enhance learning. Thus, the present study suggests that opportunities to collaborate on the entire writing process (prewriting, drafting, revising, and editing) can improve learners' writing achievement.

Another finding that might explain learning gains in this study was that nearly all participants showed positive perceptions of their experience with collaborative writing. This result is consistent with previous findings that learners perceived collaborative writing as helpful and engaging (e.g., Alkhalaf, 2020) and that collaborative writing gave them opportunities to share ideas and knowledge (e.g., Dobao \& Blum, 2013). In the present study, participants reported enjoying writing within a group and were willing to do so again. However, some group members were unwilling to accept opposing opinions. Such a situation may be unavoidable, particularly in collaborative writing, in which different opinions can lead to debates about how to organize ideas and which ideas to incorporate (Storch, 2013). Nevertheless, such discussions and collaborative decision-making suggested students were comfortable challenging each other's opinions. This process could stimulate a critical evaluation of opposing views, forcing students to generate more well-constructed ideas (Johnson \& Johnson, 1979).

\section{Conclusion}

This study adds to the growing research on collaborative writing. Small-group collaborative writing activities led to writing gains in a Saudi L2 writing classroom. Small groups benefited from a larger pool of knowledge and linguistic resources. Additionally, learners viewed collaborative writing as a valuable and enjoyable activity that contributed to their L2 writing development.

This study expands on previous research comparing individual and collaborative writing (e.g., Dobao, 2012; McDonough et al., 2019; Zenouzagh, 2020). At the same time, the study contributes to understanding the role of collaborative activities in L2 learning. Future studies should consider more data sources, such as analyzing written drafts, patterns of interaction, and stimulated recall interviews to triangulate the data and obtain a more vivid picture of learner development.

The study highlights the importance of training students before implementing collaborative writing in the classroom. Introducing collaborative work beforehand could make collaborative writing more effective, particularly in EFL contexts. Instructors should monitor activities, encourage students to take an active role, and ensure students are equally involved. Such 
Arab World English Journal (AWEJ) Volume 12. Number 3. September 2021

The Impact of Collaborative Writing on EFL Learners' Writing Development

Aldossary

procedures should make collaborative writing more effective, especially in traditionally teachercentered contexts, where students depend more on their instructors for guidance.

\section{Acknowledgements:}

The author would like to thank the Deanship of Scientific Research, King Saud University, for funding this research project.

\section{About the Author:}

Dr. Khaled ALDOSSARY is an Assistant Professor of Applied Linguistics in the Department of English Language and Translation, King Saud University, Riyadh, Saudi Arabia. He gained his Ph.D. in Applied Linguistics and Educational Linguistics from the University of Melbourne. His academic interest areas are ESL/EFL academic writing, feedback on writing, collaborative learning, and computer-mediated language learning. ORCID: https://orcid.org/0000-0002-49173258

\section{References}

Al Tai, Y. (2015). The effect of collaboration on Omani students' writing: A comparison between individual, pair and group work. European Scientific Journal. http://eujournal.org/index.php/esj/article/download/5554/5349/0

Alammar, M. (2019). A case study to compare collaborative vs. individual essay writing in Saudi male EFL learners [Doctoral dissertation, University of Limerick]. https://ulir.ul.ie/bitstream/ handle/10344/8138/Alamar_2019_Case.pdf?sequence=4

Aldossary, K. (2017). Peer feedback and the L2 writing of givers and receivers: A quantitative and qualitative longitudinal study involving Saudi students [Doctoral dissertation, University of Melbourne]. http://hdl.handle.net/11343/191750

Alkhalaf, N. A. (2020). Saudi female EFL learners and collaborative writing: Attitudes and challenges. Theory and Practice in Language Studies, 10(9), 1118-1127.

Aminloo, M. S. (2013). The effect of collaborative writing on EFL learners writing ability at elementary level. Journal of Language Teaching \& Research, 4(4).

Chen, W., \& Hapgood, S. (2019). Understanding knowledge, participation and learning in L2 collaborative writing: A metacognitive theory perspective. Language Teaching Research, 25(2), 256-281.

Dobao, A. F. (2012). Collaborative writing tasks in the L2 classroom: Comparing group, pair, and individual work. Journal of Second Language Writing, 21(1), 40-58.

Dobao, A. F. (2014). Attention to form in collaborative writing tasks: Comparing pair and small group interaction. Canadian Modern Language Review, 70(2), 158-187.

Dobao, A. F. (2020). Exploring interaction between heritage and second language learners in the Spanish language classroom. In W. Suzuki \& N. Storch (Eds.), Languaging in language learning and teaching: A collection of empirical studies (pp. 55-91). John Benjamins. https://doi.org/10.1075/1llt.55.04fer

Dobao, A. F., \& Blum, A. (2013). Collaborative writing in pairs and small groups: Learners' attitudes and perceptions. System, 41(2), 365-378.

Donato, R. (1994). Collective scaffolding in second language learning. In J. P. Lantolf \& G. Appel (Eds.), Vygotskian approaches to second language research (pp. 33-56). Ablex.

Gass, S., Mackey, A., \& Ross-Feldman, L. (2011). Task-based interactions in classroom and laboratory settings. Language Learning, 61, 189-220. 
Arab World English Journal (AWEJ) Volume 12. Number 3. September 2021

The Impact of Collaborative Writing on EFL Learners' Writing Development

Aldossary

Jacobs, H. L., Zinkgraf, S. A., Wormuth, D. R., Hartfiel, V. F., \& Hughey, J. B. (1981). Testing ESL composition: A practical approach. Newbury House.

Johnson, D. W., \& Johnson, R. T. (1979). Conflict in the classroom: Controversy and learning. Review of Educational Research, 49(1), 51-69.

Judd, T., Kennedy, G., \& Cropper, S. (2010). Using wikis for collaborative learning: Assessing collaboration through contribution. Australasian Journal of Educational Technology, 26(3), 341-354.

Khatib, M., \& Meihami, H. (2015). Languaging and writing skill: The effect of collaborative writing on EFL students' writing performance. Advances in Language and Literary Studies, 6(1), 203-211.

Long, M. H. (1996). The role of the linguistic environment in second language acquisition. In W. C. Ritchie \& T. K. Bhatia (Eds.), Handbook of second language acquisition (pp. 413-468). Academic Press.

McDonough, K., \& Sato, M. (2019). Promoting EFL students' accuracy and fluency through interactive practice activities. Studies in Second Language Learning and Teaching, 9(2), 379-395.

McDonough, K., Crawford, W. J., \& De Vleeschauwer, J. (2016). Thai EFL learners' interaction during collaborative writing tasks and its relationship to text quality. In M. Sato \& S.

Ballinger (Eds.), Peer interaction and second language learning: Pedagogical potential and research agenda (pp. 185-208). John Benjamins.

McDonough, K., De Vleeschauwer, J., \& Crawford, W. (2019). Comparing the quality of collaborative writing, collaborative prewriting, and individual texts in a Thai EFL context. System, 74, 109-120.

Namaziandost, E., \& Nasri, M. (2019). A meticulous look at Long's (1981) interaction hypothesis: Does it have any effect on speaking skill? Journal of Applied Linguistics and Language Research, 6(2), 218-230.

Sato, M., \& Ballinger, S. (2016). Peer interaction and second language learning: Pedagogical potential and research agenda. John Benjamins. https://doi.org/10.1075/11lt.45

Shehadeh, A. (2011). Effects and student perceptions of collaborative writing in L2. Journal of Second Language Writing, 20(4), 286-305.

Storch, N. (2013). Collaborative writing in L2 classrooms. Multilingual Matters. https://doi.org/10.21832/9781847699954

Storch, N. (2018b). Collaborative writing. In R. Manchón \& P. Matsuda (Eds.), Handbook of second and foreign language writing (pp. 387-406). De Gruyter Mouton.

Storch, N., \& Aldosari, A. (2010). Learners' use of first language (Arabic) in pair work in an EFL class. Language Teaching Research, 14(4), 355-375.

Swain, M. (2006). Languaging, agency and collaboration in advanced second language learning. In H. Byrnes (Ed.), Advanced language learning: The contributions of Halliday and Vygotsky (pp. 95-108). Continuum.

Swain, M. (2010). Talking-it-through: Languaging as a source of learning. In R. Batestone (Ed.), Sociocognitive perspectives on language use and language learning (pp. 112-130). Oxford University Press.

Swain, M., \& Lapkin, S. (2002). Talking it through: Two French immersion students' response to reformulation. International Journal of Educational Research, 37(3/4), 285-304.

Vygotsky, L. S. (1978). Mind in society: The development of higher psychological processes. Harvard University Press. 
Wigglesworth, G., \& Storch, N. (2012). What role for collaboration in writing and writing feedback. Journal of Second Language Writing, 21(4), 364-374.

Wood, D., Bruner, J. S., \& Ross, G. (1976). The role of tutoring in problem-solving. Journal of Child Psychology and Psychiatry, 17(2), 89-100.

Zenouzagh, Z. M. (2020). Syntactic complexity in individual, collaborative and e-collaborative EFL writing: Mediating role of writing modality, L1 and sustained development in focus. Educational Technology Research and Development, 68(6), 2939-2970.

Zhang, M. (2018). Collaborative writing in the EFL classroom: The effects of L1 and L2 use. System, 76, 1-12.

Zhang, M., \& Plonsky, L. (2020). Collaborative writing in face-to-face settings: A substantive and methodological review. Journal of Second Language Writing, 49.

https://doi.org/10.1016/j.jslw.2020.100753 